\title{
Positioning Culture within Canadian Municipalities
}

\author{
Ben Dick \\ City of Ottawa, Canada
}

Sharon Jeannotte
University of Ottawa, Canada

Kelly Hill

Hill Strategies Research, Canada

\begin{abstract}
Although sometimes still referred to as 'creatures of the province', municipalities in Canada now shape their own policies in a number of complex areas. This includes culture, since municipal cultural planning has broadened the municipal role. While municipalities still provide 'cultural services', such as arts centres and museums, cultural planning involves a more strategic role for the municipality in supporting the development of the local cultural sector, while integrating culture across many areas of municipal decision-making. The literature on organizational theory and design suggests that for municipal cultural planning to achieve these objectives, municipalities should adopt an organizational structure that supports this role. The Culture Position Study was initiated to better understand the different ways in which culture is currently situated within municipal organizational structures, and how these structures are evolving.
\end{abstract}

Keywords: culture, municipal, cultural planning, organization, structure

Résumé : Bien que les municipalités du Canada soient encore souvent qualifiées de "créatures des provinces ", force est d'admettre que leurs secteurs d'intervention sont diversifiés et qu'elles interviennent désormais dans plusieurs domaines, dont celui de la culture. Depuis longtemps, les municipalités sont reconnues comme d'importants acteurs du secteur culturel. Cette reconnaissance découle de l'offre de services culturels (musées locaux, centres d'arts municipaux), mais elle découle également de l'institutionnalisation de la planification culturelle et de la place accordée à la culture dans les activités de planification stratégique des municipalités. En s'appuyant sur les approches institutionnelles en théorie des organisations, cette recherche s'interroge sur les dynamiques de structuration qui sont à l'œuvre dans le développement des départements et services de la culture au niveau municipal.

Mots clé : culture, municipal, planification culturelle, organisation, structure

Ben Dick works for the City of Ottawa but completed the research as an independent researcher and the opinions expressed are those of the researcher. M. Sharon Jeannotte is Senior Fellow at the Centre on Governance of the University of Ottawa. Kelly Hill is the president and founder of Hill Strategies Research Inc. Email: bendick2@gmail.com

Culture and Local Governance / Culture et gouvernance locale, vol. 6, no. 1, 2019. ISSN 1911-7469 Centre on Governance, University of Ottawa, 120 university, Ottawa, Ontario, Canada K1N 6N5 


\section{Introduction}

Municipalities are complex entities.

In Canada, municipal governments are sometimes referred to as 'creatures of the province'. The role of these local governments is often associated with so-called 'hard infrastructure' (e.g. roads, bridges, and sewers), along with a few basic services like wastewater treatment and garbage collection and administration of some provincially mandated programs. However, the reality is that the role of municipalities has expanded considerably over the past several decades, and local governments now play a strategic role in many areas of public policy.

One of the areas in which municipalities in Canada now play a large (even leading) role is recreation. Municipalities began to be expected to provide recreation and leisure services in the post-WWII period. This stemmed from an agreement between the federal and provincial governments to encourage 'fitness,' broadly defined to include "social, cultural, moral, and physical aspects" (Ellis and Nixon, 1986, p. 39). The exact nature of the municipal role varied somewhat from province to province, with several provinces establishing municipal grant programs to deliver recreation services. In Ontario, during the 1950s and 1960s, the province supported "the creation of municipal recreation departments; the hiring of municipal recreation directors; the development of resource materials in arts and crafts, music, drama, social recreation, physical recreation and sports; and the establishment of English and citizenship classes for new Canadians" (Karlis, 2011, p. 43).

The broad definition of 'fitness' that was used in the post-war period meant that a municipal role in culture emerged alongside the municipal role in recreation. However, in more recent decades, a broader and more complex role for municipalities with respect to culture began to emerge. Municipalities continue to provide many of the cultural services that began as part of their role in recreation, such as arts classes and museums, but the practice of municipal cultural planning has also become common in Canada. ${ }^{1}$ This practice involves not only a role for the municipality in providing cultural amenities and supporting the development of the local cultural sector, but also the integration of culture across many areas of municipal decision-making. In fact, it could be said that what has developed is not only a broader municipal role in culture, but also the expectation of a role for culture in municipal governance.

A challenge for municipal governments is that a different role (especially if it is broader and more complex) may require a different organizational structure. Ideally, 'form follows function': each part of an organization should be set up in a way that supports its role within that organization, as opposed to trying to modify roles to fit their assigned place. Therefore, the organizational position of culture in Canadian municipalities that was established during an era in which the municipal role in culture primarily involved delivering cultural services as a form of recreation may not be suitable in an era in which much more is expected of municipalities in this realm.

However, changing organizational structures is not easy. This is especially true when the structure has been in place for a long time. Inertia is a powerful force (Greenwood and Hinings, 1988). Key players within an organization may have skills and expertise that align well with the 
current structure, so change may be perceived as threatening and met with resistance. There is a risk that the transitional costs of change may outweigh the potential benefits.

If change is going to occur, then municipalities need to consider what sort of change that should be. How should responsibility for culture be positioned within municipal organizational structures? For municipalities that already have a branch with responsibility for culture, at what point should they consider making a change? Is a complete overhaul necessary, or could more subtle changes achieve some of the same objectives with lower transitional costs?

The Culture Position Study was initiated to better understand the different ways in which culture is currently situated within municipal organizational structures in Canada, and to consider the effects that culture's organizational position can have on municipal cultural planning and policy development, allocation of resources, strategic 'visibility' in the municipal government, knowledge management, collaborative endeavours, and the relationship between the local government and the community with respect to culture. The project began with a survey of member municipalities of the Creative Cities Network of Canada (CCNC) that asked about 'culture'2 within their municipality. This is not a representative sample of Canadian municipalities. It is a sample of municipalities that have self-selected into a network that promotes the role of local governments in culture. These are municipalities that are already engaged in culture and see it as (at least partially) a municipal responsibility. Many of them have a long history in this area. In addition, CCNC is not a bilingual organization. Communications with its members are usually in English only, so CCNC has few members in Quebec. As such, the Culture Position Study survey was also in English only. A similar study of culture's position in municipalities in French-speaking regions should be a topic for future research.

As it was not a representative sample, the survey results cannot be used for statistical purposes. For this study, the survey was used mainly to identify potentially interesting cases for further study in which municipalities had realigned responsibility for culture or had established an interesting or unusual model. There were many examples to pick from. Of the 33 municipalities that responded to the survey, more than half indicated that they had gone through a significant restructuring that had affected their culture area within the previous five years. In a number of cases, noticeable impacts have emerged from a change to culture's position.

Table 1 shows the results of the initial survey. Communities with populations under 20,000 were classified as 'small,' communities with populations of 20,000 to 100,000 were classified as 'medium,' and communities with populations over 100,000 were classified as 'large.' 
Table 1: Cultural Positions, $\mathrm{N}=31$ (2 incomplete)

\begin{tabular}{|c|c|c|}
\hline Municipality & Size & Structure \\
\hline \multicolumn{3}{|l|}{ Recreation / parks } \\
\hline Port Hawkesbury, NS & Small & Part of regional government \\
\hline Minto, ON & Small & Part of regional government \\
\hline Oakville, ON & Large & Part of regional government \\
\hline Port Hope, ON & Small & Part of regional government \\
\hline Cambridge, ON & Large & Part of regional government \\
\hline St. Catharines, ON & Large & Part of regional government \\
\hline Saskatoon, SK & Large & Independent municipality \\
\hline Revelstoke, BC & Small & Part of regional government \\
\hline \multicolumn{3}{|l|}{ Planning and development } \\
\hline Northern Rockies RM, BC & Small & Regional government \\
\hline \multicolumn{3}{|c|}{ Economic/community development/finance } \\
\hline Nanaimo, BC & Medium & Independent municipality \\
\hline Capital Regional District, BC & Large & Regional government \\
\hline Stony Plain, AB & Small & Independent municipality \\
\hline Brantford, ON & Medium & Independent municipality \\
\hline Kawartha Lakes, ON & Medium & Independent municipality \\
\hline Toronto, ON & Large & Part of regional government \\
\hline Waterloo, ON & Large & Part of regional government \\
\hline \multicolumn{3}{|c|}{ Community/protective/public services } \\
\hline Pitt Meadows, BC & Small & Independent municipality \\
\hline Lethbridge, $A B$ & Medium & Independent municipality \\
\hline Okotoks, $A B$ & Medium & Independent municipality \\
\hline Fort Saskatchewan, $A B$ & Medium & Independent municipality \\
\hline Prince Albert, SK & Medium & Independent municipality \\
\hline Regina, SK & Large & Independent municipality \\
\hline Newmarket, ON & Medium & Part of regional government \\
\hline Huntsville, ON & Small & Part of regional government \\
\hline Guelph, ON & Large & Independent municipality \\
\hline Oshawa, ON & Large & Part of regional government \\
\hline \multicolumn{3}{|c|}{ City Manager's or Mayor's Office } \\
\hline District of Sechelt, BC & Small & Part of regional government \\
\hline New Westminster, BC & Medium & Part of regional government \\
\hline Victoria, BC & Large & Independent municipality \\
\hline Halton Hills, ON & Medium & Part of regional government \\
\hline \multicolumn{3}{|c|}{ Independent culture department } \\
\hline Huron County, ON & Medium & Regional government \\
\hline
\end{tabular}

We argue that municipal governments ought to consider the position of culture with in their organizational structures within the context of municipal cultural planning and the increasingly complex and strategic role that municipalities are expected to play with respect to culture. This will 
be done through a review of the changing role of municipalities, particularly as it pertains to culture, and with an examination of what can be learned from the literature on the theory of organization and design.

\section{A changing role for municipalities and the emergence of municipal cultural planning}

"Policy attachment," as Gray (2002) refers to it, is not unusual for culture. Gray defines this concept as "the idea that policy development in a certain policy area takes place through attachment of that area to other policy concerns" (Gray, 2002, p. 80). Gray explained that, since culture had traditionally been only a minor concern for local governments in the United Kingdom, it was through policy attachment that culture gained greater importance for these governments.

Throughout most of the second half of the $20^{\text {th }}$ century, municipalities in Canada primarily supported culture as a form of leisure. As Bailey (1978) described,

While federal and provincial governments have been concerned with supporting artistic excellence and innovation, it has been suggested that the local government, being most familiar with the characteristics of particular communities, may be the level of government most suited to encouraging public participation in the arts. (p. 3)

For Canadian municipalities - from the 1940 s and, in many places, continuing to the present daythis has typically meant attaching culture to recreation.

The history of culture's attachment to recreation in the Canadian municipal context can be traced back to federal-provincial fiscal arrangements following The National Physical Fitness Act, 1943. The Act established a National Council on Physical Fitness, consisting of representatives from both the federal and provincial governments. These governments divided a tiny budget among them to "train leaders, organize activities, provide facilities, and cooperate with provincial organizations" to "encourage, develop, and correlate all activities relating to the physical development of the people through sports, athletics, and other similar pursuits" (McFarland, 1970, p. 51). Although the focus was on sports and athletics, the National Council adopted a broader definition of fitness, which included social, cultural, and moral (as well as physical) fitness. The Council pointed to "the necessity of local communities providing a continuing and solid basis for programs of community recreation through a system of local tax support" (McFarland, 1970, p. 51).

The service-oriented approach that took root in the 1950s and 1960s continues to be influential in cultural policy at the municipal level. This has been reflected in the structural archetypes adopted by many Canadian cities and towns, where responsibility for cultural programming and delivery has been housed within departments or divisions responsible for parks and recreation. Even if the head of this department reports directly to the most senior person in the organization (e.g. City Manager or $\mathrm{CAO}$ ), the department often plays a limited role in strategic planning and decision-making, since its focus is service delivery (e.g. delivering programming and operating facilities). 
In the 1980s, the ground began to shift, and Canadian municipalities began to engage in municipal cultural planning. As the value of culture as a public good came increasingly under pressure in the 1980s and 1990s due to provincial and federal government austerity and cutbacks, municipalities had to spend more effort defending the support of culture solely as a recreational activity. As Johnson-Tew and Johnson have observed, "If recreation is to continue to be for the public good (as opposed to public pleasures) decision makers have to be more selective in terms of where to expend their resources" (quoted in Karlis, 2011, p. 69). Although there is no universally accepted definition of municipal cultural planning, CCNC has provided the following:

Cultural planning is a process of inclusive community consultation and decisionmaking that helps local government identify cultural resources and think strategically about how these resources can help a community to achieve its civic goals. It is also a strategic approach that directly and indirectly integrates the community's cultural resources into a wide range of local government planning activities. (Creative City Network of Canada, 2010, p. 1)

There is a lot to unpack in that definition.

First, the definition indicates that cultural planning is an 'inclusive' process, involving both the local government and the community. This seems obvious, given that culture, by its very nature, will be something that comes from communities-not something that governments can direct. However, the idea of joint government-community processes and decision-making is a shift away from the idea of governments as the 'planner/provider/deliverer' of services that emerged in the so-called Keynesian welfare state era $^{3}$ following the Second World War (the same period in which the municipal role in recreation emerged).

Second, the focus is on identifying existing cultural resources-leveraging the community's assets-as opposed to governments creating resources for the community. Again, this is a departure from the idea that governments can solve community problems or create community benefits simply by providing services or creating infrastructure. The concept of leveraging cultural resources also implies that cultural plans must be unique to the communities in which they exist. Once again, this seems obvious given the fact that culture is not culture if it's not unique. It means that there cannot be a simple script for cultural planners to follow.

Third, the cultural resources are to be used to help achieve 'civic' (not just cultural) goals. Culture is expected to play a central role in public policy. It is used to achieve objectives in other policy areas, as opposed to a service or policy that stands apart from everything else. The definition also recognizes that cultural planning is a "strategic approach" that connects to "a wide range of local government planning activities" (Creative City Network of Canada, 2010, p. 1). This requires municipal cultural planners to work with municipal decision-makers beyond the areas traditionally thought of as cultural services.

In short, municipal cultural planning is not simply a service that municipal staff can provide, a policy that municipal managers can implement, or a bylaw that elected officials can pass. It is a 
concept that sees culture as central to local governance, as opposed to just one of many services that municipal governments might provide.

The purpose of this article is not to provide a review of the practice of municipal cultural planning. Multiple researchers have examined the growth of this practice in Canada (e.g., Baeker and Runnalls, 2008; Kovacs, 2010, 2011; McVay, 2014) and noted reasons why it is occurring, such as changing economies and the popularity of Florida's (2002) creative class theory. The CCNC's definition of cultural planning is an ideal, and in reality, the practice is not likely to fully live up to this ideal. However, the important point to note is that the objectives of municipal cultural planning require a role for municipalities that is much more complex than service delivery.

\section{Applying theories of organization and design}

The search for ideal organizational structures has been ongoing since Weber (1949) first outlined the characteristics of rule-governed, hierarchical bureaucracies as the vehicles for rational public administration. Since then, bureaucratic models of organizational structures have been studied and refined with a view to understanding how and why particular forms have taken root in specific contexts.

Structural contingency theory arose from studies in the 1950s and 1960s. The theory sought to understand why the Weberian model was not always effective. It was discovered that factors, such as technology, environmental conditions, and organizational size, had an impact on the structures adopted (Child, 1972; Greenwood, 2008). However, these factors were always mediated by the strategic choices of an organization's decision makers or by the "dominant coalition" - defined by Child as "those who collectively happen to hold most power over a particular period of time" (Child, 1972 , p. 13). The dominant coalition may include not only the formally designated holders of authority, but also those who have the power to interpret information or to modify plans. The organization's posture toward the contingencies presented by its size, changes in technology, and the environment is therefore filtered through a political process influenced by the ideological values of this dominant coalition (Child, 1972).

This insight led to the development of the neo-institutional theory of organizational structure that blends the traditional focus on institutions with the focus on the importance of individual actors that emerged between the 1950s and the 1970s (March and Olsen, 1984). The new institutionalism challenged key assumptions of behaviouralist theories, such as perfect information. In reality, organizations only consider a limited number of alternatives, and there is a limited amount of information on which decisions are based. Individuals within an organization can determine which alternatives will be considered, and ultimately shape the decisions made by determining which information is gathered and presented. However, the structure of the organization, and an individual's position within that structure, can either enhance or constrain their influence in these situations (March and Olsen, 1984, p. 742).

The new institutionalism also challenged the assumption that history is 'efficient' and progresses towards an equilibrium (March and Olsen, 1984). This theory recognizes that so-called 
'rational' models of organizational efficiency were in reality socially constructed (Dobbin, 1994). As Dobbin (1994) observed, "managers believe wholeheartedly in the existence of an optimal form and engage in the quest for that form by actively searching the global environment for structures and practices that are marginally more efficient than those they already employ" (p. 137). Once adopted, these structures are shaped by local, historical processes more than by abstract notions of functional ideals.

A third influential and related conceptual stream is that of configuration or archetype theory. This theory is based on the idea that organizations have a limited number of configurations or archetypes to choose from when faced with the question of how to structure themselves to be effective. The reason for the limited number of configurations is because of continuity or path dependence: organizations evolve only gradually due to constraints imposed by existing power structures, programs, beliefs, values, and prevailing conceptions about what the organization should be doing and how it should be doing it (Greenwood and Hinings, 1988; Greenwood, 2008). The most relevant insight, for the purposes of examining culture's organizational position within local governments, is that "strategies, structures, and processes should be considered holistically" and that "multiple possible configurations (organizational forms) can achieve performance when faced with the same contingent circumstances" (Greenwood, 2008, p. 250). Like neo-institutional theory, configuration theory recognizes that the external environment is mediated by the sociocultural and political context, and that this context will shape not only the strategies adopted by the organization, but also the structures that it adopts to deliver those strategies effectively.

Moving from one structural archetype or configuration to another can take several different organizational 'tracks.' These have been described by Greenwood and Hinings (1988) in the following terms:

1) Inertia - when the organization adopts a configuration and stays with it for a lengthy period of time, usually because the existing arrangement is viewed as coherent, consistent with the organization's values, or deeply embedded in the organization's power structures;

2) Aborted excursions - when the organization moves away temporarily from the existing structural arrangement, but returns to it, usually for political or resource constraint reasons;

3) Reorientations - when an organization moves to a different configuration or archetype, usually because the existing ideas or values supporting the existing configuration have lost their legitimacy or value; and

4) Unresolved excursions - when reorganization toward a new configuration fails, but a new reorientation also fails to occur, usually because of competitive interests within the organization's power structure.

As will be discussed later, inertia in particular can be an especially powerful force.

\section{Applying organizational design theory to culture in municipal governments}

Child (1972) argued that we should not assume that organizations are products of their environments because organizations also shape their environments. Organizations (or the decision- 
makers within them) decide whom they serve, where they are located and operate, whom they should include/exclude, etc. For example, businesses can decide to relocate, expand to new markets, or develop new products for different types of customers, so their environment should not be taken as given. Similarly, governments (at any level) can decide which policies to pursue and which services to offer.

For local governments, culture is an area in which it is especially true that municipalities can shape their own environment, since there are normally only a few cultural services mandated by provincial legislation (e.g., libraries, archives), and municipalities are not normally required to create a municipal cultural plan. That said, provincial governments can (and do) influence the municipal cultural policy environment (e.g., offering incentives to create a municipal cultural plan). This type of 'vertical shaping' can result in similarities between municipalities, particularly within the same province. At the same time, municipalities are also influenced by other municipalities ('horizontal shaping') because of the pressure on managers to adopt what are perceived to be 'best practices'. This is an example of "mimetic isomorphism," which "occurs when organizations copy the cultural practices they see in the environment in order to achieve the outcomes they hope to achieve" (Dobbin, 1994, p. 126 from DiMaggio and Powell). It is important to remember, though, that municipalities decide how they respond to both vertical and horizontal influences.

The concept of mimetic isomorphism also has implications for the question of whether there is truly an 'optimum' structure that municipalities should follow. This theory does not imply that organizations are gradually discovering the optimum structure, or even that a truly optimum structure exists, but instead that organizations converge towards a particular structure simply because managers are mimicking the approach deemed to be best practice (Dobbin, 1994, p. 126).

Another important point to note is that organizations (including municipalities) do not really make decisions-people do. Therefore, to understand organizations, we must examine the individual actors within them. As Child (1972) noted, the "dominant coalition" refers to "those who collectively happen to hold most power over a particular period of time" (p. 13), which may be different from the formal designations of authority within the organization.

The processes through which a dominant coalition forms in an organization are complicated. However, to understand the power dynamics between government departments, it is worth considering Mahon's (1977) examination of the Canadian public service.

Mahon explained that the state does not really possess power-it is not a subject. Instead, the state is an "expression of the antagonistic and contradictory relations among classes and fractions" (Mahon, 1977, p. 169). Different branches of the state (often organized as 'departments' of public servants) represent different (and unequal) interests. In negotiations, the public service "acts as a 'custodian' of the basic power structure" (Mahon, 1977, p. 175).

Mahon (1966) noted that the Department of Finance tends to hold the most influential position within the Canadian state. This is to be expected. Poulantzas (1978) explained that the more the state expands, the more it depends on the economy for tax revenue. The implication is that the economic functions of the state must begin to dominate because they are needed for fulfilling the other functions of the state (Poulantzas, 1978, p. 169). 
The uneven power relationships between government departments, and the uneven interests that these departments represent, are relevant to the position of the culture branch of municipal governments. If the economic functions of the municipality are regarded as crucial to everything the municipality does, then the economic development department is not only likely to have a lot of political support and form part of the dominant coalition; it is also likely to be highly connected to decision-making processes in all areas. This is important for cultural planning, since one of the objectives is to have culture play a central role in municipal planning and decision-making.

Thinking back to Gray's concept of policy attachment, the theories provided by political economists such as Mahon and Poulantzas would seem to suggest that attachment to economic development could be quite valuable. Being connected to this influential policy area could increase the profile of culture. It could also bring culture to many decision-making tables, while helping to make connections with other areas. It is not surprising, then, that McVay's (2014, p. 21) research examining municipal cultural plans in every region of Canada found that 'economic drive' was the most dominant policy theme in these plans. Florida's creative class theory was often referenced. In addition, Kovacs (2011, p. 336), in his examination of municipal cultural plans in midsize Ontario cities, found that economic development was frequently the stated reason for creating the plan, even though the cultural planners he interviewed identified many other objectives too.

Gray (2002), however, was concerned that local government support for culture could become contingent upon support for the policy objectives to which it is attached. This means that if cultural policy fails to achieve the desired economic outcomes (e.g., talent attraction), or if these outcomes cannot be measured or definitively linked to culture, then support for culture could evaporate. This is particularly problematic given the fact that many of culture's benefits are often intangible or difficult to quantify, which is likely one of the reasons that municipalities often fail to establish mechanisms for measuring the outcomes of municipal cultural plans (Baeker and Runnalls, 2009, p. 4). There is also a risk that decision-makers may lose sight of the intrinsic value of culture.

Even if repositioning culture may be advantageous, restructuring may not occur due to inertia, as noted by Greenwood and Hinings (1988). In discussing Fligstein's (1990) study that looked at "competing managerial factions as self-interested groups that seek to promote their own expertise" (Dobbin, 1994, p. 132), Dobbin sheds light on why inertia can be such a powerful force. When an organizational structure has been in place for a long time, the managerial ranks will be filled with staff whose skills and expertise are well aligned to that model. When new managers are recruited (or promoted from within), they are likely selected based on the extent to which their resumé fits the needs of the existing structure. Attempting to impose a new structure requiring a different type of expertise could appear threatening to these managers and be met with resistance. At the same time, managers in departments that have never had much involvement with culture in the past may not have the expertise required to take on this role. 


\section{Examples of repositioning culture}

This section provides a brief overview of several cases that the researchers investigated to examine the effects of culture's position. These cases involve situations in which responsibility for culture in a municipality was restructured with noticeable impacts. These were not hard to find, as more than half of the CCNC member municipalities that responded to the Culture Position Study Survey reported recent reorganizations.

\section{The Town of Huntsville}

The Town of Huntsville is a rural community in Central Ontario with approximately 20,000 residents. The Town's Arts, Culture, and Heritage Department is located in Community Services. The current Manager of Arts, Culture, and Heritage used to also oversee recreation programming under the title of "Culture, Heritage, and Programming." Now she oversees an area with a mandate specific to culture, with three Full-Time Equivalents (FTEs) plus 11 seasonal staff. Responsibility for heritage planning has also been given to this area.

Since the Town established a specific culture manager (breaking out this role from Recreation), the community engages a lot more with the municipality with respect to culture. Having a clear voice for culture at Town Hall resulted in the community expecting the Town to play a bigger role in arts, culture, and heritage. At the same time, adding responsibility for heritage planning to this team has meant that culture staff now interact with staff in other departments, such as Planning, Building, and Geographic Information Systems (GIS). ${ }^{4}$

\section{The City of Waterloo}

The City of Waterloo is a lower-tier municipality within the Regional Municipality of Waterloo in Southwestern Ontario. The City's Arts and Culture Unit moved from the Community Services Department to the Economic Development Division of the Chief Administrative Officer's (CAO) Office following a study of the City's organizational structure in 2013. The City of Waterloo Museum remained with Community Services, but most other responsibilities of the Unit moved to Economic Development, though they are overseen by the same advisory committee of Council as before.

Being in Economic Development has meant greater access to resources, as culture staff are able to leverage Economic Development's existing relationships with the business community. The restructuring has also affected the speed with which some aspects of the City's municipal culture plan (already in place before the change) can be implemented. In Community Services, culture was a small piece of a very large department, while Economic Development is a much smaller area with fewer layers of management. Perhaps the most significant change, however, is that culture's role in Waterloo is now viewed as more strategic, particularly in the area of talent attraction and retention. In addition, culture staff are involved in more of the City's decision-making processes with departments such as Planning and Transportation. In Community Services, even when their 
department did have a seat at these tables, culture would be represented as just one of many responsibilities of the big department. ${ }^{5}$

\section{Huron County}

Huron County is an upper-tier rural municipality in Ontario with a population of approximately 60,000 . Despite being a small rural municipality, culture has its own stand-alone department. The Director of Cultural Services reports directly to the County's Chief Administrative Officer (CAO). However, the Director of Cultural Services is a combined position with the County Librarian, a position that also reports to the Library Board. There are about 38 staff in Cultural Services (34 in the library, four in culture).

Being their own department means that culture staff can set their own priorities. It also focuses the Department's expertise: culture experts make culture decisions. Paradoxically, though, having a stand-alone Culture Department can sometimes mean that other departments do not see the need to be involved in cultural affairs, as there is a sense in other departments that they do not have to worry about culture because 'that's Culture's job'. However, the linking of cultural affairs to the library has led to connections with areas such as health and social services that often work closely with the library. ${ }^{6}$

\section{The City of Regina}

The City of Regina is a provincial capital with a population of just under 200,000 . The Culture Section consists of five people, four of whom are full-time. Unlike the other cases discussed here, it has not had a major recent restructuring with respect to its culture section in the past few years. Culture is situated within Community Services, but its position in this department has evolved.

Indigenous cultural development is supported through the Community Services Department and the Social Inclusion Department, with which culture staff work closely. This aligns with the City's Cultural Plan, which includes issues related to truth and reconciliation. Grants for culture are a component of the City's Community Investment Grant Program, which supports not-for-profit organizations to deliver programming, projects, and services that improve the quality of life for residents. The Culture Section works closely with project teams responsible for renovations and capital projects, which has resulted in several new buildings that reflect the priorities of the community. However, the Culture Section has fewer connections to the economic development and tourism departments due to capacity and expertise limitations. ${ }^{7}$

\section{The City of Victoria}

The City of Victoria is a provincial capital with a population of about 367,000 . In 2015, the City's 7.5 culture FTEs were moved from the Parks, Recreation, and Culture Department to the Arts, Culture and Events Office in the Deputy City Manager's Office. This office functions as a 'one-stop shop' and 
first point of contact at City Hall for creative and cultural development requests and assistance. The creative ecosystem approach taken by the City of Victoria's Arts and Culture Master Plan has aided efforts to bridge to and collaborate with other sectors in the community.

After the move to the Deputy City Manager's Office, the cultural manager's position was eliminated, and the two senior cultural planners in the unit now report directly to the Deputy City Manager. This change resulted in the removal of three layers of management, which enabled culture staff to implement and activate cultural plans, policies, and projects at a more rapid pace. It has also meant that culture is much more 'at the table' and able to bring a 'culture lens' to discussions on infrastructure projects, economic development initiatives, wayfinding and public realm improvements, and integration of cultural spaces within other capital projects. However, responsibility for heritage continues to lie outside of the Arts, Culture and Events Office.

Culture staff now sit on many city committees and act as liaison/connectors with other parts of the City through their role on various projects. In addition, the community liaison officers in the Arts, Culture, and Events Office work closely with neighbourhoods to implement aspects of the City's cultural plan. These efforts have involved up to 40 people from other City departments, such as Parks, Engineering, and Planning. ${ }^{8}$

\section{The City of Nanaimo}

The City of Nanaimo is a stand-alone municipality with a population of just over 90,000. Its cultural operations have undergone two reorganizations since 2014. Prior to 2014, culture programs were located within the Parks, Recreation and Environment Department, and heritage programs were located in the Community Planning Section within the Development Services Department. In 2014, the City created its first Culture and Heritage Department with four employees. In 2016, this Department was moved to the Community and Cultural Planning Section within the Community Development Department, which combines the culture, heritage, and social planning functions. There continues to be a Manager of Community and Cultural Planning and two other cultural staff. The Manager reports to the Director of Community Development.

The Culture and Heritage Department was created in 2014 primarily to implement the objectives and actions identified in the City's 2014 Cultural Plan. When the Department was reorganized into the Community and Cultural Planning section in 2016, this mandate was maintained, but additional responsibilities were added, including social planning and long-range planning (dealing with Official Community Plan management, neighbourhood planning and longrange planning policy). The organizational change has not greatly altered existing programs and plans. However, the loss of a specific Culture and Heritage Department manager has affected overall leadership, resources, and motivation for completing the Culture Plan's objectives.

The 2016 reorganization was triggered by the creation of the Community Vitality Committee as part of a governance review motivated by City Council's desire to cut the number of advisory committees. The responsibilities of the Culture and Heritage Commission and the Social Planning Advisory Committee were folded into the Community Vitality Committee. The end result was to 
broaden the Committee's focus, but also lessen the amount of time that it can devote to issues in each area. ${ }^{9}$

\section{Organizational tracks for municipal culture departments}

Greenwood and Hining's (1988) analytical framework for understanding how and why organizations move from one structural archetype to another is useful in analyzing the rationales and processes behind the positioning of culture in each of the case studies. The four possible "tracks" in this framework, as mentioned above, are:

1) inertia;

2) aborted excursions;

3) reorientations; and

4) unresolved excursions.

Aspects of all four of Greenwood and Hining's tracks can be seen in the approaches taken by the municipalities discussed above.

The City of Waterloo, the City of Victoria, and Huron County offer three distinct examples of reorientation:

- culture becomes attached to a strategic policy area;

- culture becomes attached to an area with a 'bird's eye view' of the organization; or

- culture becomes its own department.

The City of Regina and the Town of Huntsville each offer an example of how subtle, but impactful, changes can occur despite some inertia by:

- culture aligning to a strategic policy area without formally changing departments; or

- culture gaining a more defined and connected role within its current department.

Our final case, the City of Nanaimo, provides an example of an aborted, or possibly unresolved, excursion.

We have summarized this information, along with the position of culture within the municipality's organization, in Table 2. As the discussion below will show, the number of management levels above the cultural division does not necessarily correlate with culture's repositioning or a 'move up' in the municipality's corporate priorities and being on an inertial track may not necessarily preclude changes in culture's role within the municipality. 
Table 2: Culture position and organization track of case study municipalities

\begin{tabular}{|c|c|c|c|c|}
\hline \multirow[b]{2}{*}{ Municipality } & \multicolumn{2}{|c|}{ Where culture sits } & \multirow{2}{*}{$\begin{array}{c}\text { Levels of } \\
\text { management } \\
\text { above }\end{array}$} & \multirow{2}{*}{$\begin{array}{c}\text { Organizational } \\
\text { Track }\end{array}$} \\
\hline & General area & $\begin{array}{l}\text { Specific culture section } \\
\text { name }\end{array}$ & & \\
\hline $\begin{array}{l}\text { City of } \\
\text { Waterloo }\end{array}$ & $\begin{array}{l}\text { Economic } \\
\text { Development }\end{array}$ & Arts and Culture Unit & 2 & Reorientation \\
\hline $\begin{array}{l}\text { Town of } \\
\text { Huntsville }\end{array}$ & $\begin{array}{l}\text { Community } \\
\text { Services }\end{array}$ & $\begin{array}{l}\text { Arts, Culture, and Heritage } \\
\text { Department }\end{array}$ & 2 & Inertia \\
\hline City of Regina & $\begin{array}{l}\text { Community } \\
\text { Services }\end{array}$ & Culture Section & 3 & $\begin{array}{l}\text { Inertia, } \\
\text { Reorientation }\end{array}$ \\
\hline City of Victoria & $\begin{array}{l}\text { Deputy City } \\
\text { Manager's Office }\end{array}$ & $\begin{array}{l}\text { Arts, Culture, and Events } \\
\text { Office }\end{array}$ & 2 & Reorientation \\
\hline Huron County & $\begin{array}{l}\text { Stand-alone } \\
\text { department }\end{array}$ & $\begin{array}{l}\text { Cultural Services } \\
\text { Department }\end{array}$ & 1 & Reorientation \\
\hline $\begin{array}{l}\text { City of } \\
\text { Nanaimo }\end{array}$ & $\begin{array}{l}\text { Community } \\
\text { Development }\end{array}$ & $\begin{array}{l}\text { Community and Cultural } \\
\text { Planning Section }\end{array}$ & 2 & $\begin{array}{l}\text { Aborted } \\
\text { excursion }\end{array}$ \\
\hline
\end{tabular}

Inertia:

Huntsville and Regina

\section{The traditional link between culture and recreation/community services remains}

There are advantages to maintaining some aspects of the status quo. As discussed earlier, the development of the municipal role in culture in Canada in the post-WWII period was closely linked to recreation. Even today, within the sample of municipalities surveyed as part of the Culture Position Study, including culture within the recreation and/or community services ${ }^{10}$ department is still the most common scenario. For municipal governments that have included culture with recreation for a long time, the managers with the most experience and knowledge of culture are likely to be in that area. Moving responsibility to a department led by managers with limited culture expertise may be challenging-even if this move might support a strategic role.

In their analysis of how the City of Toronto responded to three development applications in the West Queen West Triangle that conflicted with the City's cultural plan, McDonough and Wekerle (2011) found the City's Planning Department to be severely lacking in knowledge of culture. The neighbourhood provided living and working space for many artists and cultural workers, and the proposed developments would have resulted in a loss of some of this space. However, it was clear that Planning did not understand the value of this space, nor did it have the expertise needed to work with the developers on alternative approaches that would meet the objectives of the City's cultural plan. 
An alternative approach to a wholescale restructuring is to give culture staff a broader and more clearly defined role within their traditional department. This is what occurred in the Town of Huntsville. Creating a devoted culture manager position was not an overly ambitious undertaking. The manager was already working for the municipality, and she remained in the same department. Her title was changed slightly to Manager of Arts, Culture, and Heritage, and her role became more focused in this area. Having a clear leader for culture at Town Hall seemed to invite the community to expect more of the municipality in this area. In addition to the title change, the Manager of Arts, Culture, and Heritage was also given responsibility for heritage planning. This also did not require a major restructuring of the municipality, since the Town does not have any heritage planners on staff and had largely left responsibility for heritage planning to its Municipal Heritage Committee. Heritage planning has required culture staff to work closely with staff in the Planning, Building, and GIS departments, so it has supported cross-departmental collaboration and the integration of culture into other areas. ${ }^{11}$

In Regina, the Community Services Department has been the area primarily responsible for culture for a number of years. However, within this model, culture staff have developed very close links with the City's Social Inclusion Department. Social inclusion has become a major area of focus for the City of Regina, particularly in regard to reconciliation with Indigenous Peoples in response to the Truth and Reconciliation Commission's Calls to Action. Connecting culture to social inclusion was something the community had identified, and embracing diversity became one of the main goals of the City's cultural plan. Being in a department that works closely with Regina's communities has meant that culture staff are well-positioned to fulfill this role. ${ }^{12}$

\section{Reorientations:}

Waterloo, Regina, Victoria, and Huron County

\section{Culture becomes attached to economic development}

It should come as no surprise that 'economic drive' is the leading motivator of municipal cultural planning in Canada (McVay, 2014). Economic considerations carry a lot of weight when governments deal with competing interests. In addition to being very influential, a government's economic policy is also likely to be very connected. All governments must justify their policy decisions in economic terms, at least to some extent. Being attached to an area that is central to everything the municipality does can be helpful for cultural planners seeking to integrate culture into many areas of municipal planning and decision-making.

The case of the City of Waterloo shows the potential benefits of positioning culture with economic development. Culture staff are now involved in many more decision-making processes with departments such as Planning and Transportation, since they are no longer a small piece of a big department. This also means that implementation of the City's municipal cultural plan can move faster. ${ }^{13}$ 
Unlike recreation and community services departments that are often quite large with many layers of management within them, economic development departments are often relatively small. Many municipalities offer some 'services' in this area, such as programs that help residents start or grow a business, but municipalities cannot build and operate an economy in the same way they can (and do) build and operate recreation centres. Therefore, the municipal role in this area tends to be much less about direct delivery of services. Staff can focus more on strategic planning, as less time is consumed by day-to-day operations.

\section{Culture becomes attached to a different policy area}

The City of Regina has closely linked culture with social inclusion - an area that is clearly an area of focus for the City. Unlike with economic development, the assumption may exist that social inclusion is a 'cost,' as opposed to an 'investment' that can create revenue for all other municipal functions. However, the link between culture and social inclusion was identified by the community, ${ }^{14}$ as opposed to being something that was forced by bureaucrats or culture advocates trying to link culture to a 'strategic' area to boost its profile. This helps to address Gray's (2002) concern about cultural policy being left in an unstable position if it is tenuously attached to an area that might not be a good fit.

It should also be noted that, in addition to economic development departments, there can be other municipal departments that tend to be very connected to other areas of municipal decisionmaking. For example, planning departments are responsible for developing and administering land use policies, which will affect everything that happens on that land. The West Queen West case mentioned earlier showed how crucial planning departments can be to the success of a municipal cultural plan (McDonough and Wekerle, 2011). Nevertheless, our survey found only one case of a planning department being the area that is primarily responsible for culture. However, this finding must be treated cautiously due to the small sample size.

\section{Culture stands on its own or rises above}

As the municipal role in culture (and culture's role in municipal governance) grows larger and more complex, it is worth considering at what point it reaches a size that warrants its own department. Kovacs' (2010) study of municipal cultural planning in midsize Ontario cities found that it was common for cultural plans to recommend the creation of a dedicated area responsible for culture, though these culture offices tend to be imbedded within larger departments. To ensure that culture is fully integrated into many areas of municipal planning and decision-making, it may be best not to attach culture to any one specific area.

Although stand-alone culture departments are rare in Canadian municipalities, some municipalities are now placing culture in the City Manager's or CAO's Office. This can give culture staff a 'bird's-eye view' of the organization. In other words, culture can attach to all policy areas, without being primarily associated with any one particular area, which can help to avoid 'silos.' 
Being at this level also means that culture staff are somewhat removed from day-to-day service delivery. Similar to being in an economic development department, this usually means that there are very few layers of management.

For culture staff at the City of Victoria, moving to the Deputy City Manager's Office meant three fewer levels of management above them than they had before. Culture staff can contribute to planning and policy discussions in areas such as Parks, Planning, and Engineering, without having to work through/within the bureaucracy of these departments. The result is a culture staff that is very lean, nimble, and focused primarily on strategic planning and policy development/implementation (though they still have some service delivery roles-for example, issuing film permits).

In Huron County, culture is its own department. This is possible in a small, rural municipality partially because the public library service is included in this department. This is a very logical arrangement. After all, libraries are cultural services (as defined by the Conceptual Framework for Culture Statistics), though they are often structured separately in Canadian municipalities. Libraries in Ontario (and other provinces) are mandated services, ${ }^{15}$ which is rare for culture. Libraries have staff. In Huron County, the library makes up the vast majority of the FTEs in the Culture Department. The role of public libraries in areas such as health, social services, and education is both well established and widely understood. Other cultural domains can support those policy areas too, and attachment to the library can provide a 'way in.'

Huron County is a good illustration of the fact that municipalities may be doing more in culture, and have more 'culture staff,' than they realize. Outside of the library, there are only four culture FTEs in Huron County. However, the library has 34 FTEs, which has made culture a large enough area to warrant its own place in the County's organizational structure. Combining many of the culturerelated areas of the municipality-such as libraries, archives, museums, heritage planning, events, etc. - can create a large enough area to warrant its own department, even in a smaller community.

\section{Aborted (or possibly unresolved) excursions:}

\section{Nanaimo}

\section{Culture moves several times for political or resource reasons}

Sometimes a municipality experiments with a new orientation for culture but reverts to a past structure due to political or resource reasons. This track was evident in the case of the City of Nanaimo. Culture programs moved from Parks, Recreation, and Environment to their own Culture and Heritage Department primarily to implement the City's cultural plan, but two years later, culture was reintegrated within the Community Development Department. The manager of the culture unit is now also responsible for social planning. While a department, the culture/heritage mandate was more directed, and closer to the City Manager and Council from an organizational hierarchy perspective.

A primary motivating factor for this 'aborted excursion' appears to have been resource-related, as City Council wanted to reduce the number of advisory committees. In other cases, the reassertion 
of the priorities of a dominant coalition or a change in vision may be the primary motivations for a reversal. Although we are limited to this one case, with more than half of the municipalities in our sample reporting a significant restructuring in the previous five years, it seems that culture's position in Canadian municipalities is still in flux, so there are likely many other examples of aborted (or even incomplete or unresolved) re-positionings. This could be a topic for future study.

\section{Conclusion}

We have considered the effects that culture's organizational position can have on cultural planning and policy development, allocation of resources, strategic 'visibility' and effectiveness, knowledge management, collaborative endeavours, and the relationship between the municipality and the community with respect to culture. In doing so, we sought to answer the following questions:

- How should responsibility for culture be positioned within municipal organizational structures?

- For municipalities that already have a branch of their organization that is responsible for cultural policy, at what point should they consider a change?

- Is a complete overhaul necessary, or could smaller changes achieve many of the same objectives with less transitional costs?

The answers to these questions depend a lot on context. However, we have argued that when determining where to position culture, municipalities ought to consider this decision in the context of municipal cultural planning and the increasingly complex and strategic role that municipalities are expected to play with respect to culture.

The Culture Position Study is a first effort. The researchers hope that this initial study will spark further discussion and investigation regarding culture's 'position' in Canadian municipalities. The approach used in this study may serve as a framework for a larger study that considers a more representative sample of Canadian municipalities. Such a study could assess how the impact of organizational design factors (e.g., the policy areas with which culture is most closely aligned or the number of levels of management through which culture staff report) differ depending on contextual factors (e.g., the size of the municipality). A longitudinal study could track the outcomes of a change in the organizational structure of a municipality. Since reorganization seems to be a common occurrence in Canadian municipalities, there could be many cases to follow. In the meantime, we caution against making broad assumptions from the limited survey and case studies on which this project is based.

What the cases examined here do demonstrate, though, is that the re-positioning of culture within municipalities can take different tracks, and that there can be many reasons for an organizational position. We have seen that municipal culture staff can play a larger role in strategic planning and decision-making (as municipal cultural planning envisions) when their position in their organization is aligned in a way that supports this role. This can occur within different areas of the organization, suggesting that there is not 'one right answer' as to where responsibility for culture should be located. 
If municipal cultural planning in Canada is going to live up to its lofty objectives, then Canadian municipalities need an organizational structure that supports this role. We will continue to seek out additional cases and models to investigate. We hope to continue our collaboration with Creative Cities Network of Canada to further develop the observations noted above and turn them into a guide for municipalities.

${ }^{1}$ For a review of the state of municipal cultural planning in Canada, see McVay, R. (2014). Cultural Planning in Canada - Patterns, Theories and Authenticity. Halifax: Dalhousie University School of Planning. McVay provides examples of municipal cultural plans from almost every Canadian province and territory.

2 For the purposes of this study, 'culture' was defined as activities that fit within Statistics Canada's Conceptual Framework for Culture Statistics, 2011 <https://www150.statcan.gc.ca/n1/pub/87-542-x/87-542-x2011001eng.htm>.

${ }^{3}$ For an overview of the transition from the Keynesian welfare state to neoliberalism, and then to a postneoliberal period, see Jenson, J. (2010). “Diffusing Ideas for After Neoliberalism: The Social Investment Perspective in Europe and Latin American," Global Social Policy, Vol. 10.

${ }^{4}$ Interview with Town of Huntsville staff, September 18, 2018.

${ }^{5}$ Interview with City of Waterloo staff, October 2, 2018.

${ }^{6}$ Conversations with Huron County staff, August-September 2018.

${ }^{7}$ Conversations with City of Regina staff, August-October 2018.

${ }^{8}$ Interview with City of Victoria staff, August 28, 2018.

${ }^{9}$ Interview with City of Nanaimo staff, September 25, 2018.

${ }^{10}$ Recreation (and subsequently culture) is a branch within community services in many municipalities, so these areas are difficult to separate.

11 Interview with Town of Huntsville staff, September 18, 2018.

12 Conversations with City of Regina staff, August-October 2018.

${ }^{13}$ Interview with City of Waterloo staff, October 2, 2018.

${ }^{14}$ Conversations with City of Regina staff, August-October 2018.

${ }^{15}$ Ontario: Public Libraries Act, 1990 <https://www.ontario.ca/laws/statute/90p44> 


\section{References}

Baeker, G. and Runnalls, K. (2009). 2008-2009 Municipal cultural planning survey project: The state of municipal cultural planning in Ontario. Ontario: Ministry of Culture.

Bailey, R. (1978). The arts, people and municipalities. Toronto: Canadian Conference of the Arts.

Child, J. (1972). Organizational structure, environment and performance: The role of strategic choice. Sociology, 6(1), 1-22.

Creative City Network of Canada (2010). Cultural planning toolkit [PDF]. Retrieved from https://www.creativecity.ca/database/files/library/cultural planning toolkit.pdf

Dobbin, F.R. (1994). Cultural models of organization: The social construction of rational organizing principles. In D. Crane (Ed.), The Sociology of Culture: Emerging Theoretical Perspectives (pp. 117-141). Hoboken, NJ: Wiley-Blackwell.

Ellis, R. and Nixon, E. (1986). Saskatchewan's recreation legacy. Regina: Saskatchewan Parks and Recreation Association Inc.

Florida, R. (2002). The rise of the creative class: And how it's transforming work, leisure, community and everyday life. New York: Basic Books.

Gray, C. (2002). Local government and the arts. Local Government Studies, 28(1), 77-90.

Greenwood, R. and Hinings, C.R. (1988). Organizational design types, tracks and the dynamics of strategic change. Organization Studies, 9(3), 293-316.

Greenwood, R. (2008). Configuration Theory. In S. R. Clegg and J. R. Bailey (Eds.), International Encyclopedia of Organizational Studies (pp. 249-252). Thousand Oaks: SAGE Publications, Inc.

Jenson, J. (2010). Diffusing ideas for after neoliberalism: The social investment perspective in Europe and Latin American. Global Social Policy, 10(1), 59-84.

Johnson-Tew, P. and Johnson, R. (2005). Public recreation in the urban setting: The new reality. In T. Delamere, C. Randall and D. Robinson (Eds.), Book of abstracts: Eleventh Canadian congress on leisure research (pp. 293-96). Nainaimo, BC: Malaspina University-College.

Karlis, G. (2011). Leisure and recreation in Canadian society: An introduction (2 ${ }^{\text {nd }}$ Edition). Toronto: Thompson Educational Publishing, Inc.

Kovacs, J.F. (2010). Cultural plan implementation and outcomes in Ontario, Canada. Cultural Trends, 19(3), 209-224.

Kovacs, J. F. (2011). Cultural planning in Ontario, Canada: Arts policy or more? International Journal of Cultural Policy, 17(3), 321-340.

Mahon, R. (1977). Canadian public policy: The unequal structure of representation. In L. Panitch (Ed.), The Canadian state: Political economy and political power (pp. 165-198). Toronto, ON: University of Toronto Press.

March, J.G. and Olsen, J.P. (1984). The new institutionalism: Organizational factors in political life. The American Political Science Review, 78(3), $734-749$.

McDonough, A. and Wekerle, G.R. Integrating cultural planning and urban planning: The challenges of implementation. Canadian Journal of Urban Research, 20(1), 27-51.

McFarland, E.M. (1970). The development of public recreation in Canada. Canadian Parks/Recreation Association.

McVay, R. (2014). Cultural planning in Canada: Patterns, theories and authenticity. Halifax: Dalhousie University School of Planning. 
Ontario Ministry of Tourism, Culture, and Sport, (2017). Cultural Planning. Retrieved from http://www.mtc.gov.on.ca/en/culture/cul_planning.shtml

Ontario. 1990. Public Libraries Act, 1990. Retrieved from https://www.ontario.ca/laws/statute/90p44

Poulantzas, N. (1978). State, power, socialism. New York, NY: Verso.

Statistics Canada. (2011). Conceptual framework for culture statistics. Retrieved from https://www150.statcan.gc.ca/n1/pub/87-542-x/87-542-x2011001-eng.htm

Weber, M. (1949). The theory of economics and social organization. Glencoe, IL: The Free Press. 